\title{
The Ways to Develop Indonesian Learning Material Enriched by Local Culture for Foreign Students
}

\author{
Laily Nurlina $^{1}$, Andayani ${ }^{2}$, Retno Winarni ${ }^{3}$, St.Y. Slamet ${ }^{4}$ \\ ${ }^{1}$ Lecturers of University of Muhammadiyah Purwokerto, Indonesia \\ 2,3,4 Lecturers of Sebelas Maret University of Surakarta, Indonesia \\ Email: lailynurlina@ump.ac.id
}

\begin{abstract}
Mastering Indonesian language is a crucial thing although it is not one of requirements to study in Indonesia. The foreign students need to speak in Indonesian language because people like to communicate in same language. That's why many Indonesian Language Teaching Institutions for Foreign Students (ILTIFS) provided some services to conduct Indonesian learning especially in Central Java- Indonesia. This study is purposed to describe an effort to develop Indonesian learning material for foreign students enriched by local culture. Learning language means learning its culture, foreign students need to know local culture so they can communicate contextually and avoid from shock culture in early living here. The paper used qualitative description to explain four steps on developing learning material.
\end{abstract}

Keywords

develop, Indonesian

learning material,

describe, local culture,

foreign students

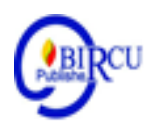

\section{Introduction}

Indonesian language has been communication tool among countries around ASEAN (Association of Southeast Asian Nations) regional. The number of foreign students increased significantly in Indonesia. They studied through three ways; Indonesian as communicative tool, art and culture to know habit, social life and sociocultural to understand Indonesian community. These can be learnt by studying Indonesian language integrated with culture. The development of Indonesian teaching in Indonesia required good learning materials and based on the students' need. Teachers must be more creative in developing learning materials to be more interesting and favoured by students (Darmuki, et.al., 2018). People studied culture using some processes, for example seeing, predicting, feeling, staying and connecting with others (Stuart et.al.,1996). In the learning of Indonesian language, they also studied habit, attitude, ethics, and environment.

The learning process will occur well through interactive processes between students and teachers, students with students, and students with learning materials. Besides that students learn naturally, and mental processes occur where students connect new information to relevant concepts (Rangkuti in Syakur (2020).

Learning Bahasa Indonesia for foreign speakers nowadays is a necessity as more and more people study in Indonesia. The absence of requirement for Indonesian language competency test for foreign students resulted in different communication skills in the usage of Indonesian language. They experience a culture shock since they are unable to communicate in Indonesian and do not understand the local culture around their environment. To overcome this problem, many universities establish The Indonesian Language Teaching Institutions for Foreign Students (ILTIFS). These institutions were created initially to assist foreign students to speak Indonesian so that they did not prepare adequate teaching materials. 
The teachers have not considered the content of local culture which is very important to overcome the foreign students' culture shock.

The development teaching materials containing local culture has not been prepared to a large extent. Tomlinson (2005) defines teaching materials as everything that is used to help teach language students, it can be textbooks, student workbooks, tapes, CD Rom, videos, photocopied handouts, newspapers, paragraphs written on the board: everything that represents or informs about the language being studied. Teaching materials should have an impact on students when students become more curious, interested and attentive to the material being taught."

Foreign students have no language preparation to study in Indonesia but they communicate using Indonesian language here. They need to learn Indonesian language contextually so that they can avoid cultural shocks. Adaptation of foreign students in a host country, developed during the process of acculturation, is complex and differentiated, since it occurs in the context of a dialogue of representatives of different nationalities, a dialogue of cultures (Ahtarieva,et.al.: 2018). This has been observed by Oradee (2012) who compared three communication activities and students' attitude in speaking learning process. The results of his research indicate that his method is able to increase the students' speaking skill, which is similar to the results of Boonkit's study (2010). Oradee examined students but Boonkit observed teachers' effort to improve students' speaking skill. Thailand students felt worried and had low self- confidence because they didn't communicate in real situation. He recorded the activity, collected the data and analysed them. Some ways to improve students' speaking skill include speaking to music, watching movies, speaking to the radio, watching TV and multimedia. Another research by Paramasivan (2013) developed learning materials for pilots and air traffic controllers. The material contained speaking material using cooperative and collaborative method among experts.

Harmer (2012) adapted speaking classroom, which started with motivation so that students are actively involved in communication. Indonesian teachers prepared learning materials and activities, and give feedback to students so that their speaking ability will increase in every meeting. This research aims to develop learning material enriched by Central Java local culture represented by Banyumas, Solo, and Semarang based on Koentjaraningrat's theory (1994). Authentic material is useful for increasing foreigners' attention and motivation because it is contextual and very close to their daily life in Indonesia. Practically, teaching language and culture cannot be separated (Dietter, 1991). The learning material development is purposed to increase Indonesian speaking ability of foreign student. It is time for speaking skill to be given bigger part because it influences foreign students' ability to communicate in daily life. They can communicate based on context if they understand rules in the local culture. This culture does not only refer to dance or traditional clothes but also habit, gesture, politeness, rules about social relation, and many more.

\section{Methods}

The primary aim of this research is to develop an Indonesian learning material containing local culture for foreign students. The product will be systematically tested in the field (ILTFIS), evaluated, and revised until the whole criteria are completed (effectiveness, quality, and foreign students' needs). 


\section{Review of Literature}

\subsection{Review of Literature}

The previous speaking material was analysed using descriptive explanative analysis to identify the usage and quality, and examine the importance of speaking material containing local culture for foreign students. There are some techniques in this step like (1) questionnaires which consist of some questions related to speaking material, (2) in-depth interviews with foreign students and their teachers, (3) observations of foreign Indonesian learning classroom, and (4) content analysis of Indonesian speaking material for foreign students.

The constant comparative method compares learning material and descriptive analysis to describe the data (Strauss \& Corbin, 1990). Some related analysis components are (1) determining information, (2) making information category based on similarity information characteristics, (3) determining categories of relationship, and (4) developing theory based on categories relationship.

\subsection{Development Stage}

The development of Indonesian material enriched by local culture was done in some stages in order to get its feasibility by its practicality, time to implementation, foreign students' response and attitude. Some cycles were combined between Zuber Skerrit model and Glanz cycle as references in the material development. The prototype in each stage was tested, evaluated, revised, and implemented in Indonesian classroom for foreign students.

\subsection{Procedures in Determining the Indonesian Learning Material Enriched by Local Culture for Foreign Students}

The procedures are (1) testing speaking material containing local culture for foreign students material prototype, (2) reviewing speaking material containing local culture for foreign students in terms of content, performance, and appropriateness, (3) identifying deficiency of speaking material containing local culture for foreign students, (4) revising the deficiency of speaking material containing local culture for foreign students, (5) reviewing the appropriateness of speaking material containing local culture for foreign students, including conducting Focus Group Discussion and expert judgement, and (6) repeating the development cycle until the material was appropriate.

\subsection{Testing the Indonesian Learning Material Enriched by Local Culture for Foreign Students}

This method is used to test the effectiveness of learning material in three ILTIFS Central Java, namely two control classes and one experiment class. The validity and reliability item tests used content validity before and after test. The location was the University of Muhammadiyah Purwokerto as experiment class, Sebelas Maret University Surakarta and University Sport Semarang as control classes. Before doing the treatment, validity test and reliability test were done to obtain content validity for the questions in before and after test. This test was aimed at knowing the effectiveness of learning material and analysed the material by inferential statistics technique t-test.

The instruments were constructed by judgement expert namely questionnaire on teacher's need, questionnaire on foreign students' needs, and before-after test. They were considered valid if the instruments can measure what can be measured (Sugiyono: 2011). The result of questionnaire validity is 10 items for student questionnaire, 10 items for teacher 
questionnaire, and before-after 25 multiple choice tests. After finding the valid item test, we can say that the item test is valid if the correlation coefficient (rxy) rtabel in significance 5\% level (Burhan et al., 2004:339). Reality exam before and after test used excel for speaking test $(\mathrm{r} x y)$ is 0.619 . Score $r$ table $n=24$ mistake level 5\% got 0.404 and mistake level $1 \%$ got 0.515. Because result $\mathrm{r}$ is greater that $\mathrm{r}$ table for mistake level $5 \%$ and $1 \%$ $(0.619>0.515>0.404)$, it can be concluded that the test instrument is reliable for this research.

\section{Results and Discussions}

Three Indonesian Language Teaching Institutions for Foreign Students (ILTIFS) in Central Java have separated materials between Indonesian language skills and culture information. Based on the previous analysis, we can see the ILTIFS got some problems such as (a) speaking is rarely taught because teachers need special preparation especially if the instructor does not have their own teaching material; (b) there is no adequate audio facilities for teaching speaking; (c) foreign students experienced difficulties in learning culture through text and they rarely learn verbally; (d) another obstacle when using teaching materials from other ILTIFS is understanding the materials and culture which are different in terms of the students' real conditions, (e) most of the materials are not speaking materials according to what happens in everyday life; (f) speaking materials are in the form of reading dialogues so that it results in boredom and less challenge, $(\mathrm{g})$ learning for foreign speakers is not only for the transfer of knowledge but it also focuses on improving communication skills in a social context, (h) speaking material is not limited to practice; there are theories that are difficult for foreign speakers to practice but should be more communicative and in accordance with the local culture where foreign speakers live, and (i) cultural shock experienced by foreign students can be reduced by providing knowledge of local culture and how they can apply it in the Indonesian environment.

The results of the needs analysis are as follows: (a) learning materials are needed at ILTIFS, (b) the need for learning materials filled with Central Java local culture in the form of theory and practice, which can be realized in books and videos, (c) Learning material grips need to be developed with the content of the local culture of Central Java, (d) teaching textbooks are equipped with syllabi and methods of teaching Indonesian for foreign speakers so that it makes it easier for teachers, (e) speaking process in the classroom is carried out more communicatively equipped with audio speaking and video, (f) the importance of teaching materials containing local culture so that foreign students do not need to learn twice; they do not need to study in two different classes namely language class and cultural class, (g) cultural knowledge is very important especially with regard to communication and social methods information with the surrounding community, and (h) culturally, teaching materials should bridge communication and speaking-based learning materials. These eight results were in line with the research of Hermayati (2016) which indicated that teaching materials with cultural values and preserving culture would make students understand Indonesia as a whole. 
Table 1. Content Culture Analysis on Indonesian Language Learning Books for Foreign Students:

\begin{tabular}{|c|c|c|c|c|}
\hline No & Book Title & Author & Publisher & Cultural Content \\
\hline 1 & $\begin{array}{l}\text { Berbicara } \\
\text { BIPA } 1\end{array}$ & $\begin{array}{l}\text { Kartika } \\
\text { Kusworatri }\end{array}$ & LBI UI & No culture discussion. \\
\hline 2 & $\begin{array}{l}\text { Lentera } \\
\text { Indonesia } 2\end{array}$ & ILTIFS team & $\begin{array}{l}\text { Pusat Bahasa } \\
\text { Departemen Pendidikan } \\
\text { Nasional Republik } \\
\text { Indonesia }\end{array}$ & $\begin{array}{l}\text { 1. There is a cultural vocabulary. } \\
\text { 2. Discourse text contains local culture } \\
\text { discussion. } \\
\text { 3. Some images describing local culture } \\
\text { understanding. }\end{array}$ \\
\hline 3. & $\begin{array}{l}\text { Lentera } \\
\text { Indonesia } 3\end{array}$ & ILTIFS Team & $\begin{array}{l}\text { Pusat Bahasa } \\
\text { Departemen Pendidikan } \\
\text { Nasional Republik } \\
\text { Indonesia }\end{array}$ & $\begin{array}{l}\text { 1. Local culture material is widely } \\
\text { discussed in this book. } \\
\text { 2. There are } 4 \text { out of } 12 \text { units with themes } \\
\text { of Indonesian culture. } \\
\text { 3. Discourse texts provide a lot of local } \\
\text { cultural information from various regions } \\
\text { in Indonesia such as Betawi, Sunda, East } \\
\text { Nusa Tenggara, and Central Java. }\end{array}$ \\
\hline 4. & Keren!(1) & Ian J. White & $\begin{array}{l}\text { Pearson Education } \\
\text { Australia Pty Limited }\end{array}$ & No culture discussion. \\
\hline 5. & Keren!(2) & Ian J. White & $\begin{array}{l}\text { Pearson Education } \\
\text { Australia Pty Limited }\end{array}$ & $\begin{array}{l}\text { 1. Introduce Nusantara terms with } \\
\text { English as the language of instruction } \\
\text { 2. The habit of Indonesians, almost every } \\
\text { family has a maid. } \\
\text { 3. The condition of Muslim families does } \\
\text { not keep dogs as pet. } \\
\text { 6. The term of rubber clock. } \\
\text { 7. Uniform use at school. } \\
\text { 8. Manners. } \\
\text { 9. Benefits of an identity card. }\end{array}$ \\
\hline 6. & $\begin{array}{l}\text { Bingkai } \\
\text { Bahasa } \\
\text { Indonesia } 1\end{array}$ & $\begin{array}{l}\text { Tim BIPA } \\
\text { UNJ }\end{array}$ & FBS UNJ & $\begin{array}{l}\text { The versatile part of Indonesia that } \\
\text { explains the unique things in Indonesia. }\end{array}$ \\
\hline 7. & $\begin{array}{l}\text { Bingkai } \\
\text { Bahasa } \\
\text { Indonesia } 2\end{array}$ & $\begin{array}{l}\text { Tim BIPA } \\
\text { UNJ }\end{array}$ & FBS UNJ & $\begin{array}{l}\text { There are } 2 \text { units discussing traditional } \\
\text { transportation, puppet shows, and batik. }\end{array}$ \\
\hline 8. & $\begin{array}{l}\text { Bingkai } \\
\text { Bahasa } \\
\text { Indonesia } 3\end{array}$ & $\begin{array}{l}\text { Tim BIPA } \\
\text { UNJ }\end{array}$ & FBS UNJ & $\begin{array}{l}\text { There are } 3 \text { units discussing archipelago } \\
\text { culinary, traditional marriage, and } \\
\text { cultural tourism. }\end{array}$ \\
\hline 9. & $\begin{array}{l}\text { Bingkai } \\
\text { Bahasa } \\
\text { Indonesia } 4\end{array}$ & $\begin{array}{l}\text { Tim BIPA } \\
\text { UNJ }\end{array}$ & FBS UNJ & $\begin{array}{l}\text { The Indonesian all-round section } \\
\text { discusses social gathering, mutual } \\
\text { cooperation, and others. }\end{array}$ \\
\hline 10. & PILAR & $\begin{array}{l}\text { Dwi } \\
\text { Puspitorini }\end{array}$ & PBS UNJ & No culture discussion. \\
\hline 11. & $\begin{array}{l}\text { Komunikasi } \\
\text { Situsasional }\end{array}$ & $\begin{array}{l}\text { Dwi } \\
\text { Puspitorini, } \\
\text { Nunung } \\
\text { Nuryanti, } \\
\text { Cynthia } \\
\text { Vientani, }\end{array}$ & $\begin{array}{l}\text { Program BIPA LBI- } \\
\text { FIBD-UI }\end{array}$ & No culture discussion. \\
\hline
\end{tabular}




\begin{tabular}{|c|c|c|c|c|}
\hline & & $\begin{array}{l}\text { Nening } \\
\text { Sukesti }\end{array}$ & & \\
\hline 12. & $\begin{array}{l}\text { Colloquial } \\
\text { Indonesia }\end{array}$ & $\begin{array}{l}\text { Sutanto } \\
\text { Atmosumarto }\end{array}$ & $\begin{array}{l}\text { England by Biddles Ltd, } \\
\text { Stoodleigh, Devon. }\end{array}$ & No culture discussion. \\
\hline 13. & $\begin{array}{l}\text { Materi Ajar } \\
\text { BIPA- } \\
\text { Tingkat } \\
\text { Menengah } 1\end{array}$ & $\begin{array}{l}\text { Elsya } \\
\text { Yulianti, R. } \\
\text { Maesaroh, } \\
\text { Sri } \\
\text { Nurasiawati }\end{array}$ & Balai Bahasa UPI & $\begin{array}{l}\text { Some themes about childhood memories } \\
\text { in the countryside, traditional games, } \\
\text { siskamling, traditional food, and myths in } \\
\text { Indonesia. }\end{array}$ \\
\hline 14. & $\begin{array}{l}\text { Modul } \\
\text { BIPA UNY }\end{array}$ & $\begin{array}{l}\text { Nurhadi, Ari } \\
\text { Kusmiatun, } \\
\text { B. Yuniar } \\
\text { Diyanti, Tri } \\
\text { Kartika } \\
\text { Handayani, } \\
\text { Andika } \\
\text { Rahmadi P. }\end{array}$ & KUI UNY & $\begin{array}{l}\text { 1. Cultural content is in Teropong } \\
\text { Budaya section but not available in every } \\
\text { unit. } \\
\text { 2. Material such as older brothers/sisters } \\
\text { call in local languages, traditional games, } \\
\text { angkringan culture, social gathering, } \\
\text { massage and kerokan, and the tradition of } \\
\text { Mudik. } \\
\text { 3. There are } 2 \text { units that contain material } \\
\text { with cultural contents, namely Baju Teluk } \\
\text { Belanga Shirt and Kuda Lumping. }\end{array}$ \\
\hline
\end{tabular}

From Table 1, some books are integrated and contented a little local culture so that foreign students got difficulties to practise contextual Indonesian language in daily life. Data from the questionnaire and in- depth interview show the necessity of learning material enriched by local culture. The foreign students and the teacher also suggested some themes to make the learning material better.

By having such kind of books analysing above so the learning material has developed and enriched by Central Java culture to make foreign students learnt Indonesian easily and contextually. Then, Focus Group Discussion processes were done and gave some results: first, designing a syllabus for Indonesian learning with local culture for foreign students in Central Java. This process considers the standards of competence, basic competencies, and learning objectives. The second is developing competency standards by changing some adjustments according to the students' need. The third is describing the eight competency standards into a number of basic competencies according to the context of the environment and local culture. The fourth is designing four different methods of Indonesian learning at each meeting adjusted to the themes of lectures, discussions, brainstorming, and role playing. The fifth step of the FGD is arranging the material framework tailored to the standards of competence and basic competencies and ranking the themes. The sixth is developing a material framework into teaching materials that are in accordance with the need analysis in the exploration phase. This activity is at the core of the preparation of teaching materials with the contents of local culture of Central Java. All input from the instructors in the FGD was taken into consideration in developing teaching materials.

The prototype was sent to two Indonesian language experts to improve it. The experts gave some suggestions as follows : (1) the content is too easy for Intermediate level; (2) the culture knowledge is good and communication part should be added; (3) the topic is relevant and up to date; (4) it still lacks of speaking activity; (5) it lacks of complex materials; (6) review on grammar should be provided; (7) the material needs outing activity, (8) it needs better pictures ; (9) pay attention on the choice of words; (10) give some simple instructions in speaking activities; (11) delete some useless sentences; and (12) change name into real Javanese name. Validation and consultation with experts have provided inputs and 
suggestions for improvement so that the prototype could be a useful teaching material for ILTIFS. Teaching materials validated by experts were in the forms of prototypes of Indonesian teaching handbooks, prototypes of Indonesian learning handbooks, audio and video conversations containing local culture in Central Java.

Both experts provide meaningful inputs for the development and improvement of this teaching material so that it can be implemented for a wider audience.

The next step was conducting the evaluation on learning material in ILTIFS Universitas Muhammadiyah Purwokerto. The teacher took Unit 1 Raden Kamandaka for the first meeting and gave some inputs, such as foreign students look more enjoyable; they are more enthusiastic to look for difficult words; and they learnt culture without reading thick books. The experiment research involved three Indonesian learning institutions, one as experiment class and two as control classes. Every class had ten foreign students from various countries and same level Indonesian speaking ability. The level of normality test can be seen below:

Table 2. The Result Test of Normality on Experiment Class

\begin{tabular}{lcccc}
\hline No & Group & Value of Sig. & Confidence Level & Decision \\
\hline 1 & A & 0.235 & 0.05 & Normal data \\
\hline 2 & B & 0.220 & 0.05 & Normal data \\
\hline 3 & C & 0.225 & 0.05 & Normal data \\
\hline
\end{tabular}

Table 3. The Result Test of Homogeneity on Experiment Class

\begin{tabular}{lccccl}
\hline No & Group & Df & p-value & Confidence Level & \multicolumn{1}{c}{ Decision } \\
\hline 1 & A & 10 & 0.715 & 0.05 & Normal data \\
\hline 2 & B & 10 & 0.928 & 0.05 & Normal data \\
\hline 3 & C & 10 & 0.927 & 0.05 & Normal data \\
\hline
\end{tabular}

The homogeneity test results above showed that the value of sig is greater than 0.05 . It means the variance of population is homogeneous.

Table 4. The Result of Speaking Test

\begin{tabular}{llllll}
\hline Group & \multicolumn{1}{c}{ Class } & Mean & $\begin{array}{c}\text { Std. } \\
\text { Deviation }\end{array}$ & N \\
\hline A & Experiment & 7.3 & 0.66 & 10 & \\
\hline B & Control 1 & 6.8 & 0.70 & 10 & \\
\hline C & Control 2 & 6.8 & 1.2 & 10 & \\
\hline
\end{tabular}

Every ILTIFS in Central Java has their own teaching materials that are used according to their needs according to the syllabus made by the Language Development and Development Agency (PPSDK). The purpose of prototyping was to find out the deficiencies and ineffectiveness of prototypes in terms of both material and audio quality. After knowing the deficiencies of the prototype, the prototype can be improved through several stages and finally a dummy can be made. The syllabus is a source guideline in the development of Indonesian learning starting from the making of learning plans, the management of Indonesian learning, and the development of a scoring system. The Indonesian learning syllabus design process was discussed by instructors in the FGD by considering the competency standards, basic competencies, and learning objectives. The lecturers discussed the competency standards in CEFR (Common European Framework of Reference for Languages) and those in the 2014 Balai Bahasa Indonesian material mapping.

The standard of intermediate level competency at the CEFR is being able to express opinions about abstract matters related to culture in a limited manner, give instructions, and understand general instructions or announcements. The competency standards refered to in 
the 2014 Balai Bahasa material mapping are: (M1.1) able to understand the main topics about everyday things encountered in work, education, and leisure; (M1.2) able to understand and express in a rather complex and clear language about various things related to personal interests; (M1.3) able to understand and express in oral and written forms various things about the surrounding environment; (M1.4) able to express thoughts and feelings quite smoothly when facing various situations when visiting Indonesia, especially in cultural aspects; (M2.1) able to briefly express experiences, events, hopes and ambitions accompanied by reasons; (M2.2) able to understand the main idea of a complex text and with regard to topics that are appropriate in their fields, both concrete and abstract; (M2.3) able to interact by expressing ideas spontaneously and quite smoothly without significant constraints on certain themes related to the surrounding environment, such as in the society and current issues; and (M2.4) able to produce clear and detailed texts on various subjects of conversation and explain points of view on certain topics while expressing weaknesses and strengths from that point of view.

One of the competencies that must be mastered by foreign student is speaking Indonesian fluently and understandable. Barieva,Kh.et.al (2018) in his study discussed about the overcoming of barriers in communication is depending on teacher's competence to create learning situation and adapt the structure of the lesson's technological map for the targeted work. Speaking skills have basic competencies such as being able to participate in a conversation about topics that are common about every day interests or concerns spontaneously, for example about family, hobbies, jobs, tours, and daily activities, conveying a clear description or explanation and detailed on various topics related to interest, able to convey descriptions in oral form on certain topics related to activities in the surrounding environment, able to handle situations that require speaking skills if visiting Indonesia, able to arrange words in a simple way to describe experiences and events, hopes, or ideals, able to convey arguments in discussions, speeches, and lectures with spontaneous speech and clear pronunciation, able to convey ideas spontaneously and quite smoothly without significant constraints in certain themes related to environment, such as in the society and current issues, and able to explain opinions about something.

Three times trials showed the strengths of this developed material containing local culture for foreign students: (a) foreign students were used to learning the material so that they were more ready to speak; (b) foreign students were more active during Indonesian learning process and asked some questions; and (c) it was easier for Indonesian teachers to teach because they did not need to prepare their own materials as the speaking material was ready. The weaknesses were (a) the necessity of vocabulary list so that teachers did not waste too much time explaining them, and (b) the necessity of picture on each unit to help foreign students understood the content.

The improvement was done after the trials was giving more instructions in every activity so the teacher can implement the material communicatively, adding vocabulary list, and combining reading text with speaking activity. The speaking syntax to implement speaking material containing local culture for foreign students were (1) the teacher conveyed the aim of Indonesian learning specially in the speaking activity; (2) the foreign students read the text as a preliminary activity before speaking activity; (3) the foreign students listened to the audio to get prior knowledge; (4) the foreign students formed discussion groups, and (5) speaking activity included describing, monolog, dialogue, and conversation.

The fourth stage in this development research was to answer the question "How is the effectiveness of Indonesian learning material enriched by local culture for foreign students?". To answer the question, the researcher conducted an experiment based on the provisions that have been determined previously in the research methodology. The test results were analyzed 
to find out the differences between the use of Indonesian teaching materials developed and teaching materials commonly used by ILTIFS. This stage was carried out to examine the effectiveness and feasibility of developed material with local cultural content for foreign students in Central Java so that it could be used in ILTIFS.

One of important things in the development of learning materials was the existence of an evaluation tool to measure the understanding of learning material enriched by the local culture of Central Java. An evaluation tool was made in the form of various kinds of speaking assignments. After the learning material became a prototype, the next process was editing. The editing of the manuscript was carried out by re-reading texts, correcting writing errors and linguistics. Auditing audio editing and local culture videos by watching it, recording dialect errors, dialogues, or disturbing voices. Researchers improved books, audio and video scripts until they were suitable for using.

The data on speaking ability at the ILTIFS - UMP, UNS, and UNNES show that there were differences in abilities when compared to the use of developed learning materials. Therefore, Ha was accepted. The test results of teaching materials developed were in line with Hermiyati's (2006) and Kawuran's (2013) research which aimed to relate teaching materials with cultural values so that students could understand Indonesia as a whole. The advantage gained from culturally charged material was that students were not uprooted from cultural roots even though they learn foreign cultures; they were close to the everyday environment and foster a multicultural spirit. Andayani (2005) showed the same test results that Indonesian textbooks for foreign students integrated with local culture were able to improve the understanding of culture and communication skills. Introducing local culture to foreign students will increase poly cultural understanding. Poly cultural education promote harmonization of relations between representatives of different civilizations and cultures (Achaeva,et.al.:2018). The presence of a multicultural environment allows stimulating the interest of foreign students in new knowledge.

\section{Conclusion}

The results showed that the instructional material developed was able to significantly improve the students' speaking skills. The efforts done to provide solutions to the problems faced by ILTIFS teaching were by developing learning materials in the form of student handbooks, teaching handbooks, speaking audio, and dialogue videos containing local culture.

The benefits that can be obtained by Indonesian teachers from developing this learning material were: (1) teachers can develop other learning materials with local culture according to their students' needs; (2) it reduced dependence on teaching materials from other ILTIFS; (3) the process added knowledge and experience related to the development of developed materials, and (4) the relationship between teachers and foreign students was improved closer because of good communication in using the developed materials. The benefits that can be obtained by foreign students from developing this learning material were (1) this learning material provided additional learning references so that the learning materials became more varied; (2) students could learn independently because this teaching material was equipped with audio and video; and (3) students could easily repeat the material they want to master. 


\section{References}

Achaeva,et.al. (2018). Intercultural Education in the System of Training Future Teachers. Journal of Social Studies Education Research. 9(3). http://files.eric.ed.gov/fulltext/EJ1190156.pdf

Ahtarieva,et.al. (2018). Integration as a Form of Acculturation of Foreign Student-Future Teacher in the Polyethnic Educational Environment of University. Journal of Social Studies Education Research. 9(3). http://files.eric.ed.gov/fulltext/EJ1190217.pdf

Alwi, Hasan. (2011). Butir - Butir Perencanaan Bahasa. Jakarta : Budaya Pengembangan dan Pembinaan Bahasa Kementerian Pendidikan dan Kebudayaan. http://repositori.kemdikbud.go.id/1779/1/Politik\%20Bahasa\%20\%282011\%29.pdf

Andayani. (2015). The Correlation of Learning Motivation and Reasoning Ability to Scientific Writing Skills of Students in Teaching Indonesian to Speakers of Other Languages (TISOL). International Journal of Science and Research (IJSR). Vol 4. Issue 7 July 2015.pp 1106 - 1110. https://www.ijsr.net/archive/v4i7/v4i7.php

Arikunto, Suharsimi. (2006). Prosedur Penelitian Suatu Pendekatan Praktik. Jakarta: Rineka Cipta

Barieva,Kh. et.al. (2018). The Overcoming the Communication Barriers of Students as Means of a Personalization of Education. Journal of Social Studies Education Research.9(3). https://files.eric.ed.gov/fulltext/EJ1190172.pdf

Boonkit, Kamonpan. (2010). Enhancing The Development Of Speaking Skills For Nonnative Speakers Of English. Procedia Social Sciences. Vol.12. https://www.sciencedirect.com/science/article/pii/S1877042810002314

Cangara, Hafied. (2010). Pengantar Ilmu Komunikasi. Jakarta : Rajawali Press.

Darmuki, A.,Andayani, Nurkamto,J\& Saddhono,K. (2018). The Development and Evaluation of Speaking Learning Model by Cooperative Approach. International Journal of Instruction. Vol 11(2). 115-128. https://files.eric.ed.gov/fulltext/EJ1174930.pdf

Ducker and Saunders. (2014). Facilitating Extensive Speaking with Non - Graded Materials in EFL Programs. International Journal of Innovation in English Language Teaching $\begin{array}{llllll}\text { and } & \text { Research. Volume 3. Number 2.pp } 201 & - & 214\end{array}$ https://www.novapublishers.com/catalog/product_info.php?products_id=14903

Harmer, Jeremy. (2012). The Practise of English Language Teaching. UK: Pearson

Hastanto, Sri. (2011). Kesenian Jawa sebagai Media Pemertahanan Bahasa dan Sastera Jawa. Makalah pada Kongres Bahasa Jawa V Tahun 2011.Institut Seni Indonesia (ISI) Surakarta. http://staffnew.uny.ac.id/upload/131570315/penelitian/MAKALAH-KBJ2011.pdf

Hermayati,N. Pengaruh Penggunaan Teknik Discussion Starter Story terhadap Kemampuan Berfikir Kreatif Peserta Didik. UPI (2016). Unpublished.

Kartawinata, Ade M. (2011). Meretas Kearifan Lokal di Tengah Modernisasi dan Tantangan Pelestarian : Pengantar Editor Buku Kearifan Lokal di Tengah Modernisasi. Jakarta : Kementerian Kebudayaan dan Pariwisata Republik Indonesia.

Koentjaraningrat. (1994). Kebudayaan Jawa : Seri Etnografi Indonesia. Jakarta : Balai Pustaka

Nurgiyantoro, B et.al. (2004). Statistik Terapan untuk Penelitian Ilmu-ilmu. Sosial. Yogyakarta. Gadjah Mada University Press.

Oradee, Thanyalak. 2012. Developing Speaking Skills Using Three Communicative Activities (Discussion, Problem Solving, and Role Playing). International Journal of Social Science and Humanity. Vol.2. No.6. November 2012. http://ijssh.org/papers/164-A10036.pdf 
Paramasivam, S. (2013). Materials Development for Speaking Skills In Aviation English For Malaysian Air Traffic Controllers: Theory and Practice. The Journal of Teaching English For Specific And Academic Purposes. Vol.1. No.2. pp 97 - 122. http://espeap.junis.ni.ac.rs/index.php/espeap/article/view/42

Strauss,A \& Corbin,J. Qualitative Analysis. (1990 NY: Cambridge University Press).

Stuart,Harbone W. (1996). Local Search and the Evolution of Technological capabilities. http://doi.org/10.1002/smj.425017004.

Sugiyono. (2010). Statistika untuk Penelitian. Bandung : Alfabeta.

Syakur, A, at al. (2020). The Effect of Project Based Learning (PjBL) Continuing Learning Innovation on Learning Outcomes of English in Higher Education. Budapest International Research and Critics in Linguistics and Education (BirLE) Journal. P. 625-630 